\title{
BEST PAPER NASS 2013: LINK-N CAN STIMULATE PROTEOGLYCAN SYNTHESIS IN THE DEGENERATED HUMAN INTERVERTEBRAL DISCS
}

Rahul Gawri ${ }^{1,2,3,4}$, John Antoniou ${ }^{2,3}$, Jean Ouellet ${ }^{1,3,4}$, Waleed Awwad ${ }^{3,4,6}$, Thomas Steffen ${ }^{1,3}$, Peter Roughley ${ }^{3,5}$, Lisbet Haglund 1,3,4 and Fackson Mwale ${ }^{2,3, *}$

${ }^{1}$ Orthopaedics Research Laboratory, Royal Victoria Hospital, McGill University, Montréal, Canada

${ }^{2}$ Orthopaedics Research Laboratory, Lady Davis Institute for Medical Research - Jewish General Hospital, Montréal, Canada

${ }^{3}$ Department of Surgery, McGill University, Montréal, Canada

${ }^{4} \mathrm{McG}$ ill Scoliosis and Spine Center, McGill University, Montréal, Canada

${ }^{5}$ Shriners Hospital for Children, Montréal, Canada

${ }^{6}$ King Saud University, Riyadh, Saudi Arabia

\begin{abstract}
Intervertebral disc (IVD) degeneration is the most common cause of back pain. Presently there is no medical treatment, leaving surgery as the only offered option. Here we evaluate the potential of Link-N to promote extracellular matrix regeneration in human IVDs. Human disc cells cultured in alginate and intact human discs were exposed to a combination of Link-N and ${ }^{35} \mathrm{SO}_{4}$ in the presence or absence of interleukin (IL)-1, and the effect on proteoglycan synthesis was evaluated. In addition, message levels of aggrecan, matrix metalloproteinase (MMP)-3, MMP-13, a Disintegrin And Metalloproteinase with Thrombospondin Motifs (ADAMTS)-4 and ADAMTS-5 were evaluated in alginate cultures. Human disc cells responded in a dose dependent manner with maximal proteoglycan synthesis at $1 \mu \mathrm{g} / \mathrm{mL}$ Link-N. Link-N treatment also induced proteoglycan synthesis in intact human discs, and a prolonged effect was found up to one week after Link-N treatment. Message levels of proteinases were decreased by Link-N in the presence of IL-1. Thus, Link-N can promote proteoglycan synthesis and deplete proteinase expression in adult human discs. Link-N could therefore be a promising candidate for biologically-induced disc repair, and could provide an alternative to surgical intervention for early stage disc degeneration.
\end{abstract}

Keywords: Human intervertebral disc degeneration; regeneration; tissue engineering; organ culture; proteoglycans; bioactive peptides; Link-N; biological repair.

\footnotetext{
*Address for correspondence:

Fackson Mwale

Lady Davis Institute for Medical Research

Sir Mortimer B. Davis - Jewish General Hospital

3755 Chemin Cote Ste Catherine,

Montréal, Canada, H3T 1E2

Telephone Number: (514)-340-8222 Ext. 2948

FAX Number: (514)-340-7502

E-mail:fmwale@1di.jgh.mcgill.ca
}

Introduction

Low back pain is strongly associated with intervertebral disk (IVD) degeneration (Luoma et al., 2000), and is one of the leading chronic illnesses requiring physician care and utilization of the healthcare system (Frymoyer and Cats-Baril, 1991). It is ranked $6^{\text {th }}$ among the costliest health conditions, and has a high recurrence rate which adds to the cost of treatment (Engel et al., 1996; Luo et al., 2004; Dagenais et al., 2008). The direct costs involve the cost for medical devices, surgeries, hospitalizations, physiotherapy, etc. (Dagenais et al., 2008). The main treatment modality offered is surgical, which is associated with morbidities and complications that further increase the cost of healthcare (Mapel et al., 2004). IVD degeneration has been widely attributed to elevation in cytokine levels in the disc, which in turn elevates levels of aggrecanases and all matrix metalloproteinases (MMPs) including Disintegrin And Metalloproteinases with Thrombospondin Motifs (ADAMTSs) that cleave aggrecan and other matrix components (Akyol et al., 2010). Fragmentation and loss of aggrecan, the most abundant proteoglycan present in the IVD, results in loss of disc height, and its neurological sequelae lead to back pain (Chung et al., 2003; Roughley, 2004; Roughley et al., 2006b).

Biological repair therapies thus have to simultaneously be aimed at increasing aggrecan content in the disc and downregulating MMP and cytokine production to shift disc homeostasis towards anabolism. Many strategies have been proposed and a few tested to repair and/or regenerate IVDs biologically. Among them the most common ones evaluated are injection of growth factors or bioactive peptides, gene therapy, cell injections, and implantation of hydrogel-based medical devices (Chadderdon et al., 2004; Anderson et al., 2005; Boyd and Carter, 2006; Zhao et al., 2007; Woods et al., 2011; Chan and Gantenbein-Ritter, 2012a).

The use of growth factors and bioactive growth factorlike peptides in particular has caught much attention (Freemont et al., 2002; Yoon, 2005). Some growth factors have shown promise in restoring the proteoglycan content of the IVD (Masuda et al., 2004; Imai et al., 2007a; Imai et al., 2007b). However, cost effectiveness and safety has been an issue with the use of recombinant growth factors. Thus, emphasis has shifted towards bioactive peptides for biological treatment of disc degeneration.

Link-N peptide (DHLSDNYTHDLDRAIH) is the $\mathrm{N}$-terminal part of link protein, a glycoprotein that 
stabilizes the non-covalent interaction between the aggrecan G1 domain and hyaluronate. (Melching and Roughley, 1985). It is generated in vivo by proteolytic degradation of link protein by MMPs during tissue turnover (Donohue et al., 1988), and has been shown to increase proteoglycan synthesis and production of other matrix components by bovine IVD cells (Mwale et al., 2003). Recently, Link-N injection has also been shown to increase disc height in a rabbit disc puncture degeneration model (Mwale et al., 2011), showing the regenerative potential of the peptide in vivo. However, there are no reports of the effect of Link-N in human IVDs or of the effect in an inflammatory environment.

In this study, we have evaluated the regenerative potential of Link-N peptide in a human IVD whole organ culture system (Gawri et al., 2011), which is at present the closest system to human in vivo studies. These analyses have enabled us to establish Link-N as an effective anabolic agent in the disc, and possibly a cheaper and safer alternative to surgical treatment of disc degeneration.

\section{Materials and Methods}

\section{Materials}

L ink - N (D H L S D N Y T L D H D A I H) and 5-TAMRA conjugated Link-N were synthesized by CanPeptide (Pointe Claire, QC, Canada). 5-TAMRA (5-carboxytetramethylrhodamine) was from Ana Spec Inc., (Fremont, CA, USA). Pronase was from Calbiochem (Darmstadt, Germany). Collagenase 1A, GlutaMAX, $\mathrm{NaCl}$, sodium citrate and EDTA were purchased from Sigma-Aldrich (St. Louis, MO, USA). Low viscosity alginate (Keltone LV), was obtained from Kelco Chemical Co. (San Diego, CA, USA). Penicillin/streptomycin, gentamicin sulfate, amphotericin B, Dulbecco's Modified Eagle's Medium (DMEM) and fetal calf serum (FCS) were obtained from Gibco (Burlington, ON, Canada). 20G 1.5 inch needles to make alginate beads and U-100 insulin syringes with $25 \mathrm{G}$ needles to inject intact discs were obtained from BD syringes (Concord, ON, Canada). RNA Easy $^{\mathrm{TM}}$ kit for RNA isolation and Omniscript ${ }^{\mathrm{TM}}$ Reverse Transcription kit were purchased from Qiagen, (Toronto, ON, Canada). RT-PCR kit, Taqman reagent and Taqman primers and probes were from Applied Biosystems (Foster City, CA, USA). Gas permeable sterile bags were obtained from VWR International (Ville Mount Royal, QC, Canada).

\section{Source of tissues}

Human thoracolumbar spines were harvested through the organ donation program of Transplant Quebec. Discs were from 13 donors, 6 males and 7 females, covering an age range of 16 to 72 years, (mean of 38.25 years). The age and gender of the donors and the discs recovered from each spine are shown in Table 1. A complete surgical and medical history was obtained for each donor. Donors that had had recent chemotherapy, radiation therapy to the spine, or significant long-standing paralysis were excluded from the study. Spine retrieval was performed within 8 hours of death. Up to 8 motion segments were obtained per spinal column. Discs with calcification and loss of disc height were not included in the study. All procedures were approved by the institutional review board of the Montreal General Hospital.

Bovine tails from 18-27 months old steers were obtained from a local abattoir within 6 hours of sacrifice.

\section{Isolation of human and bovine IVD cells}

Human and bovine IVDs were separated from the adjoining vertebral body and divided into nucleus pulposus (NP) and annulus fibrosus (AF) for bovine IVDs and NP and inner annulus fibrosus (iAF) for human IVDs. Tissue from the human outer annulus fibrosus (oAF) was not used for cell isolation in this study. This methodology was followed as human discs are easily demarcated into NP, $\mathrm{iAF}$ and $\mathrm{oAF}$ regions, whereas the bovine discs from the age range used in this study can only be demarcated into $\mathrm{NP}$ and AF regions. Moreover, the oAF region in human discs is not a major site for proteoglycan synthesis. Cells were enzymatically isolated from the separated regions as previously described (Roughley et al., 2006a). Briefly, NP and AF tissues were dissected into approximately $2 \mathrm{~mm}$ thick pieces, washed twice in PBS containing $50 \mu \mathrm{g} / \mathrm{mL}$ gentamicin, $100 \mu \mathrm{g} / \mathrm{mL}$ penicillin, $100 \mathrm{U}$ streptomycin and $0.25 \mu \mathrm{g} / \mathrm{mL}$ fungizone, then digested with $0.2 \%$ pronase for $1 \mathrm{~h}$, followed by collagenase type IA at $0.01 \%$ for NP and $0.04 \%$ for AF tissue for $4 \mathrm{~h}$ in serum free DMEM.

Table 1: Identification of Human Intervertebral Disc (IVD) Donors.

\begin{tabular}{|c|c|c|c|c|}
\hline Donor & Age (years) & Sex & Cause of Death & Disc Levels \\
\hline 1 & 72 & $\mathrm{~F}$ & $\mathrm{ICH}$ & L4-L5 \\
\hline 2 & 30 & M & Gunshot & L4-L5 \\
\hline 3 & 29 & $\mathrm{M}$ & $\mathrm{ICH}$ & L1-L2, L2-L3, L3-L4, L4-L5 \\
\hline 4 & 59 & $\mathrm{M}$ & $\mathrm{ICH}$ & T12-L1, L1-L2, L2-L3, L3-L4, L4-L5 \\
\hline 5 & 42 & $\mathrm{~F}$ & $\mathrm{ICH}$ & L2-L3,L3-L4, L4-L5, L5-S1 \\
\hline 6 & 53 & $\mathrm{~F}$ & $\mathrm{ICH}$ & L1-L2, L2-L3,L3-L4, L4-L5, L5-S1 \\
\hline 7 & 30 & $\mathrm{M}$ & MVA & L1-L2, L2-L3,L3-L4, L4-L5, L5-S1 \\
\hline 8 & 26 & $\mathrm{M}$ & Electrocution & L1-L2, L2-L3,L3-L4, L4-L5, L5-S1 \\
\hline 9 & 61 & $\mathrm{~F}$ & $\mathrm{ICH}$ & L1-L2, L2-L3,L3-L4, L4-L5 \\
\hline 10 & 21 & $\mathrm{~F}$ & Cocaine Overdose & T9-T10, T10-T11, T11-T12, T12-L1, L1-L2, L2-L3, L5-S1 \\
\hline 11 & 20 & $\mathrm{~F}$ & MVA & T9-T10, T10-T11, T11-T12, T12-L1, L1-L2, L2-L3,L3-L4, L5-S1 \\
\hline 12 & 16 & $\mathrm{~F}$ & Cardiac Arrest & T9-T10, T10-T11, T11-T12, T12-L1, L1-L2, L5-S1 \\
\hline
\end{tabular}

$\mathrm{ICH}=$ Intracranial Hemorrhage, MVA= Motor Vehicle Accident. 


\section{Alginate embedding of IVD cells and culture}

Isolated cells were embedded in $1.2 \%$ alginate beads as previously described (Maldonado and Oegema, 1992) using $20 \mathrm{G} 1.5$ inch needles. Cells in alginate beads were cultured at $37^{\circ} \mathrm{C}, 5 \% \mathrm{CO}_{2}$ in DMEM, containing $4.5 \mathrm{~g} / \mathrm{L}$ of glucose and supplemented with $10 \% \mathrm{FCS}, 25 \mathrm{mmol} / \mathrm{L}$ HEPES, $50 \mu \mathrm{g} / \mathrm{mL}$ of gentamicin sulfate, $0.25 \mu \mathrm{g} / \mathrm{mL}$ fungizone, $50 \mu \mathrm{g} / \mathrm{mL}$ L-ascorbate, and $2 \mathrm{mmol} / \mathrm{L}$ GlutaMAX. The beads were stabilized for 7 days and cell viability was assessed by the Live/Dead ${ }^{\circledR}$ assay prior to further treatment. Five beads per well were then cultured in 48-well plates in the presence of Link-N peptide in concentrations ranging from $0.01 \mu \mathrm{g} / \mathrm{mL}$ to $10 \mu \mathrm{g} / \mathrm{mL}$ in $0.5 \mathrm{~mL}$ DMEM. $25 \mu \mathrm{Ci}$ / $\mathrm{mL}^{35} \mathrm{SO}_{4}$ was added to the medium to allow assessment of proteoglycan synthesis (Malemud et al., 1991). In addition, beads were exposed for $48 \mathrm{~h}$ to interleukin- $1 \beta$ (IL-1 $\beta)(10 \mathrm{ng} / \mathrm{mL})$, Link-N $(1 \mu \mathrm{g} / \mathrm{mL})$ or a combination of Link-N and IL-1 $\beta$ (Le Maitre et al., 2005). At the end of the culture period, medium was collected and dialyzed exhaustively against miliQ water at $18.2 \Omega$ (Spectr/Por 3, $3500 \mathrm{kDa}$ molecular weight cut-off dialysis membrane) followed by cold chase with $1 \mathrm{M} \mathrm{MgSO}_{4}$ for $2 \mathrm{~h}$ to remove any remaining unincorporated ${ }^{35} \mathrm{SO}_{4} \cdot{ }^{35} \mathrm{SO}_{4}$ incorporation was measured using a beta scintillation counter (Beckman Coulter LS6500; Beckman, Missisauga, ON, Canada).

\section{RNA isolation}

Alginate beads containing cells were dissolved using sterile PBS supplemented with $150 \mathrm{mM} \mathrm{NaCl}, 55 \mathrm{mM}$ sodium citrate and $28 \mathrm{mM}$ EDTA. Cell pellets were collected after spinning at $500 \mathrm{~g}$ for $5 \mathrm{~min}$. Total RNA was extracted using an RNA Easy ${ }^{\mathrm{TM}}$ kit following the manufacturer's instructions. RNA concentrations and purity were determined by measuring $\mathrm{A}_{260}$ and by calculating the $\mathrm{A}_{260} /$ $\mathrm{A}_{280}$ ratio, respectively.

\section{Real-time PCR}

Total RNA isolated from the cells from each group was digested with DNAase I and used for reverse transcription using an Omniscript ${ }^{\mathrm{TM}}$ Reverse Transcription kit. cDNA from $1 \mu \mathrm{g}$ RNA was mixed with random primers to a final volume of $20 \mu \mathrm{L}$ and used per reaction well of RT reactions, using Taqman ${ }^{\circledR}$ chemistry run with a 7500 Fast Real Time system (Applied Biosystems). Genes analysed were aggrecan, MMP-3, MMP-13, ADAMTS-4 and ADAMTS-5, with $18 \mathrm{~S}$ ribosomal RNA as a housekeeping gene. Gene expression was calculated using the $\Delta \Delta \mathrm{Ct}$ method (Livak and Schmittgen, 2001).

\section{IVD isolation for organ culture}

IVDs were prepared for whole organ culture by removing vertebral bone and retaining cartilaginous endplates, as previously described (Gawri et al., 2011; Jim et al., 2011). The discs were rinsed once in Dulbecco's phosphate buffered saline (PBS) and twice in 2 x Hank's Balanced Salt Solution supplemented with $100 \mu \mathrm{g} / \mathrm{mL}$ gentamicin sulfate and $0.5 \mu \mathrm{g} / \mathrm{mL}$ fungizone. Intact discs were cultured in a standard incubator at $37{ }^{\circ} \mathrm{C}, 5 \% \mathrm{CO}_{2}$. The discs were kept in sterile $100 \mathrm{~mL}$ polymethylpentene containers for 3 days in $3.5 \mathrm{~mL} / \mathrm{g}$ tissue of DMEM supplemented with $25 \mathrm{mmol} / \mathrm{L}$ HEPES, $50 \mu \mathrm{g} / \mathrm{mL}$ gentamicin sulfate,
$0.25 \mu \mathrm{g} / \mathrm{mL}$ fungizone, $50 \mu \mathrm{g} / \mathrm{mL}$ 1-ascorbate, $2 \mathrm{mmol} / \mathrm{L}$ GlutaMAX, $1 \mathrm{~g} / \mathrm{L}$ glucose and $1 \%$ FCS. Based on preliminary experiments, $3.5 \mathrm{~mL}$ of medium was added per $\mathrm{g}$ of tissue; this provides enough volume to completely cover the discs during the culture period. The discs were then transferred to $4 \mathrm{oz}$ (approx. $113 \mathrm{~g}$ ) sterile gas permeable sampling bags containing $20 \mathrm{~mL}$ of medium in order to minimize the amount of ${ }^{35} \mathrm{SO}_{4}$ used for radiolabeling. The discs were maintained under confined swelling without application of external load. Under these conditions, the disc initially swells and reaches an equilibrium in which the swelling is equivalent to the maximum degree observed during diurnal loading in vivo (Gawri et al., 2011). Subsequently the disc behaves as if it is maintained under static load.

\section{${ }^{35} \mathrm{SO}_{4}$ incorporation in response to Link-N treatment}

IVDs were matched according to grade of degeneration assessed radiologically and designated to control or experimental groups. Link-N was prepared at a concentration of $20 \mathrm{mg} / \mathrm{mL}$ in DMEM, and the $\mathrm{pH}$ was adjusted to 7.4 using $1 \mathrm{~N} \mathrm{NaOH}$. For discs designated to the experimental group, $50 \mu \mathrm{L}$ of Link-N was mixed with $50 \mu \mathrm{L}^{35} \mathrm{SO}_{4}(1 \mathrm{mCi} / \mathrm{mL})$ and injected into the center of the disc using a $1 \mathrm{~mL}$ insulin syringe, U-100 with $25 \mathrm{G}$ needle. After injection, the needle was gradually removed in a twisting manner to avoid backflow. A total of $1 \mathrm{mg}$ Link-N was injected per disc. The control group received $50 \mu \mathrm{L}^{35} \mathrm{SO}_{4}$ and $50 \mu \mathrm{L}$ DMEM medium. The discs were maintained in culture in sterile bags as described above for $48 \mathrm{~h}$. Samples were taken at the center of the disc and circumferentially at a distance of $1 \mathrm{~cm}$ from the center using a $4 \mathrm{~mm}$ skin biopsy punch. The tissue samples were digested with proteinase $\mathrm{K}(1 \mathrm{~mL}$ of $1 \mathrm{mg} / \mathrm{mL}$ per $100 \mu \mathrm{g}$ wet weight tissue) at $56^{\circ} \mathrm{C}$ for $8 \mathrm{~h}$ (Hollander et al., 1994), then $0.5 \mathrm{~mL}$ of digest was dialyzed and analyzed for ${ }^{35} \mathrm{SO}_{4}$ incorporation.

To evaluate if there is a sustained effect of Link-N, discs were injected on day 1 , with or without Link-N, as described above. Cultures were maintained for 7 days with one medium change at day 4 . At day 7 , both control and experimental discs were injected with $100 \mu \mathrm{L}^{35} \mathrm{SO}_{4}$ $(1 \mathrm{mCi} / \mathrm{mL}){ }^{35} \mathrm{SO}_{4}$ incorporation was evaluated after $48 \mathrm{~h}$, as described above.

\section{Link-N diffusion within the disc}

To assess Link-N diffusion within the discs, 5-TAMRA -conjugated Link-N was injected at a concentration of $10 \mathrm{mg} / \mathrm{mL}$ in an injection volume of $100 \mu \mathrm{L}$. An equivalent amount of unconjugated 5-TAMRA was injected in separate discs as control. The injected discs were cultured in $20 \mathrm{~mL}$ medium, and $100 \mu \mathrm{L}$ medium samples were collected at regular intervals. 5-TAMRA fluorescence was assessed using an Infinite ${ }^{\circledR}$ M1000 Pro instrument (Tecan, Grödig, Austria) at $535 \mathrm{~nm}$ excitation and $585 \mathrm{~nm}$ emission. The samples were collected until 5 consecutive medium samples gave similar values indicating that no more fluorescent Link-N was diffusing from the discs. The medium was then repeatedly changed every $2 \mathrm{~h}$ until no fluorescent signal was detected. An $8 \mathrm{~mm}$ punch was taken at the site of injection together with four circumferential 


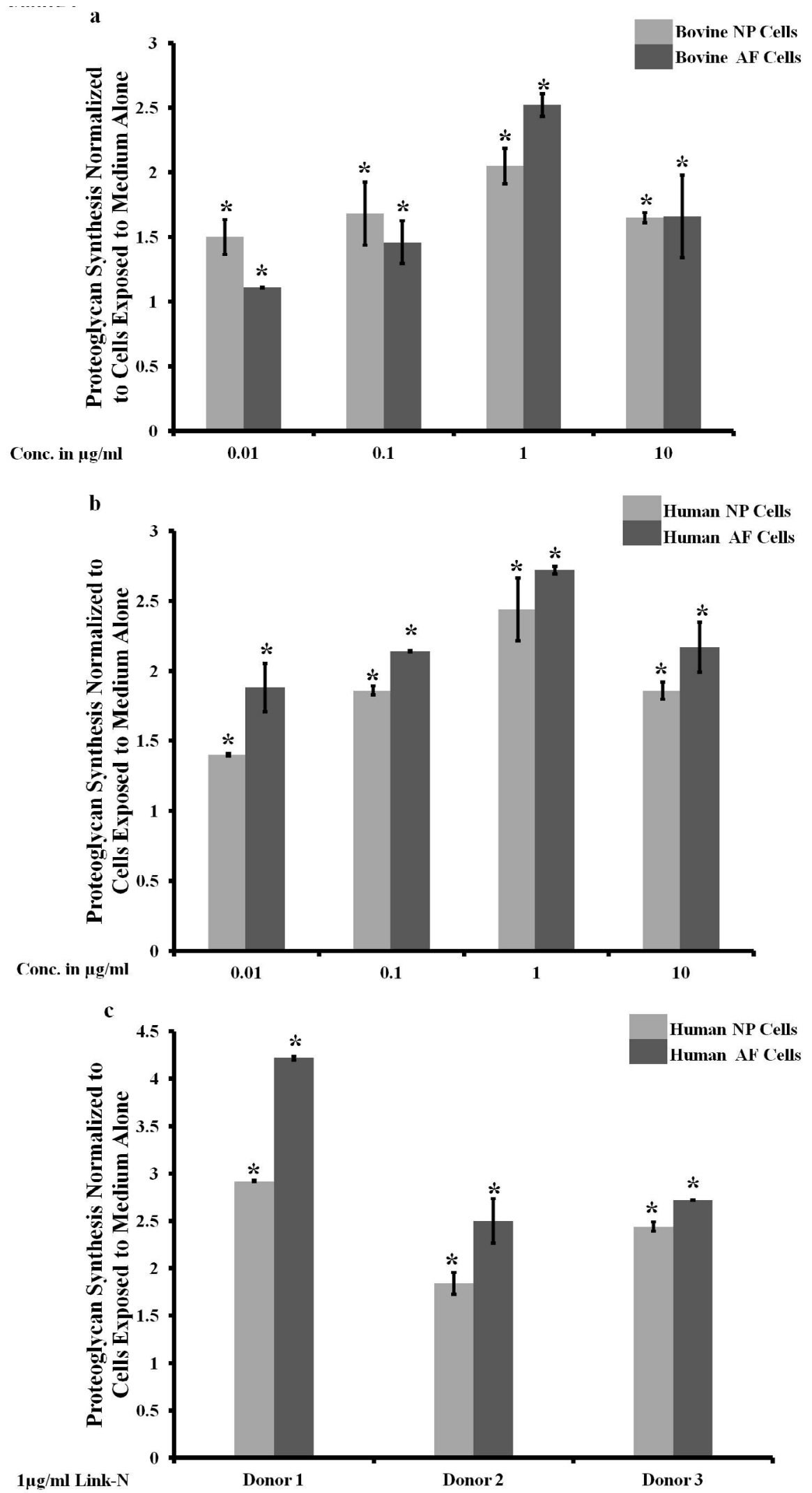

Fig.1. (a) Changes in proteoglycan synthesis by bovine nucleus pulposus (NP) and annulus fibrosus (AF) cells, $48 \mathrm{~h}$ after Link-N or media supplementation. (b) Changes in proteoglycan synthesis by human nucleus pulposus (NP) and inner annulus fibrosus (iAF) cells, $48 \mathrm{~h}$ after Link-N or media supplementation. Proteoglycan synthesis by bovine or human disc cells beaded in alginate was estimated by evaluating ${ }^{35} \mathrm{SO}_{4}$ incorporation. Data are plotted as ratio relative to incorporation by control cells exposed to medium alone. (c) Donor variation in proteoglycan synthesis by human nucleus pulposus (NP) and annulus fibrosus (AF) cells, $48 \mathrm{~h}$ after Link-N or media supplementation. ${ }^{35} \mathrm{SO}_{4}$ incorporation was evaluated at the dose of maximal response $(1 \mu \mathrm{g} / \mathrm{mL})$ of Link-N by NP and AF cells, beaded in alginate, from four different donors. Each donor had its own control and data are plotted as a ratio relative to control. Values where $p \leq 0.05$ (*) were taken as significant. 
Fig. 2. Changes in Aggrecan, MMP-3, MMP13, ADAMT S-4, and ADAMTS-5 gene expression by human nucleus pulposus (NP) and annulus fibrosus (AF) cells beaded in $1.2 \%$ alginate, $24 \mathrm{~h}$ after Link -N(1 $\mu \mathrm{g} / \mathrm{mL})$ or medium supplementation. Data are expressed as a ratio relative to gene expression by cells exposed to medium alone. Values where $p \leq 0.05(*)$ were taken as significant.

Fig. 3. Changes in Aggrecan, MMP-3, MMP13, ADAMTS-4, and ADAMTS-5 gene expression by annulus fibrosus (AF) and nucleus pulposus (NP) cells beaded in $1.2 \%$ alginate, $24 \mathrm{~h}$ after Link-N $(1 \mu \mathrm{g} / \mathrm{mL})+\mathrm{IL}-1$ (10 ng/mL) or IL-1 (10 ng/ $\mathrm{mL})$ alone supplementation. Data are expressed as a ratio relative to gene expression by cells exposed to IL-1 alone. Values where $p \leq 0.05(*)$ were taken as significant.
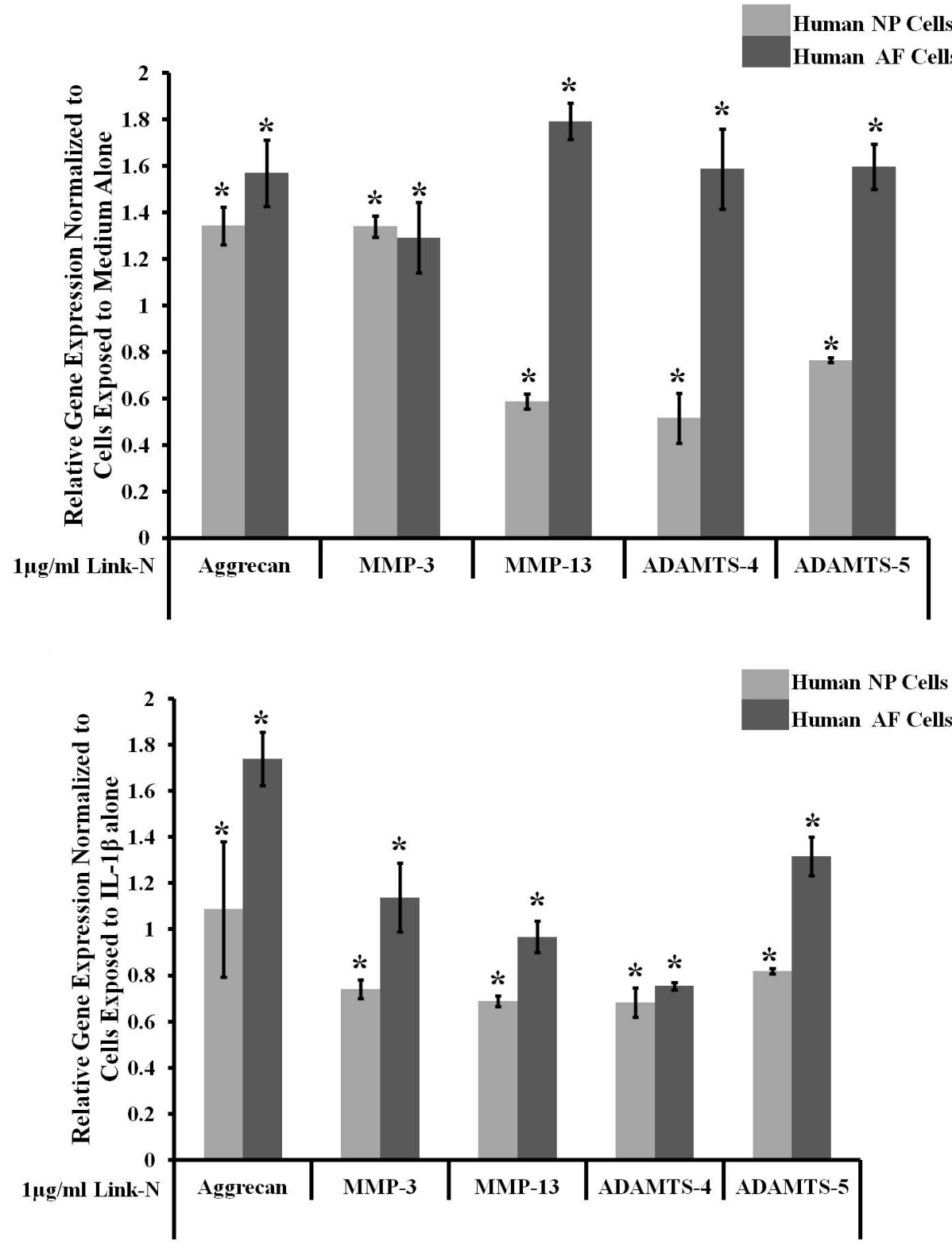

$4 \mathrm{~mm}$ punches at $1 \mathrm{~cm}$ distance from the site of injection. The tissue punches were digested with proteinase $\mathrm{K}$ and fluorescence was measured as described above. Results are presented as relative fluorescence units (RFUs) per $100 \mu \mathrm{g}$ wet weight tissue.

\section{Cell viability}

Viability was measured using the LIVE/DEAD ${ }^{\circledR}$ Viability/ Cytotoxicity Assay (Life Technologies, Burlington, ON, Canada).

\section{Statistical analysis}

The results were expressed as mean and standard error of mean (SEM). Relative ratio and relative standard deviation (RSD) was calculated with designated control set at 1 . Statistical analysis was done using two tailed paired $t$-test for two samples for means with $p$ values $<0.05$ taken as significant.

\section{Results}

Assessment of the Link-N concentration resulting in maximal proteoglycan synthesis by NP and AF cells ${ }^{35} \mathrm{SO}_{4}$ incorporation was used to assess proteoglycan synthesis in response to Link-N exposure. NP and AF cells were exposed to $0.01 \mu \mathrm{g} / \mathrm{mL}$ to $10 \mu \mathrm{g} / \mathrm{mL}$ Link-N for $48 \mathrm{~h}$. Bovine disc cells from NP and AF regions showed a statistically significant dose dependent increase in proteoglycan synthesis in response to Link-N, with maximal response at $1 \mu \mathrm{g} / \mathrm{mL}(\mathrm{NP} p=0.003, \mathrm{AF} p=0.004)$ (Fig. 1A). AF cells showed a stronger response at the dose of maximal response than NP cells at the same Link-N concentration $(p=0.0192)$. Human cells showed a similar trend, with the same dose of maximal response (NP $p=0.002$, AF $p=0.001$ ) (Fig. 1B). In the same manner as for bovine cells, human AF cells showed a stronger response than NP cells $(p=0.03)$. To determine if there was variability between donors, disc cells from 
Fig. 4. Changes in proteoglycan synthesis of the annulus fibrosus (AF) and nucleus pulposus (NP) cells, $48 \mathrm{~h}$ after IL, IL + Link-N, or Link-N supplementation. NP and AF cells beaded in $1.2 \%$ alginate were exposed to $1 \mu \mathrm{g} / \mathrm{mL}$ of Link-N and/ or $10 \mathrm{ng} / \mathrm{mL}$ of IL-1 $\beta$. Exposure to $10 \mathrm{ng} / \mathrm{mL}$ of IL- $1 \beta$ was taken as control. Proteoglycan synthesis was estimated by evaluating ${ }^{35} \mathrm{SO}_{4}$ incorporation. Data are expressed as a ratio relative to proteoglycan produced by cells exposed to IL-1 alone. Values where $p \leq 0.05(*)$ were taken as significant.

Fig. 5. Proteoglycan synthesis by human intact discs $48 \mathrm{~h}$ after Link-N injection. Increase in proteoglycan synthesis was evaluated by estimating ${ }^{35} \mathrm{SO}_{4}$ incorporation in intact human IVDs in organ culture injected with $1 \mathrm{mg} /$ disc of Link-N. (A) Donor variation. IVDs were taken from different donors from same level (L2-L3) matched to their control in grade of degeneration. Although the discs always showed enhanced proteoglycan synthesis after Link-N injection, a high degree of variation was observed in discs from different donors. (B) Level variation. IVDs were taken from different levels from the same donor matched to their control in grade of degeneration. All data are expressed as a ratio of response shown by the adjacent level individual control discs injected with medium alone set to 1 .
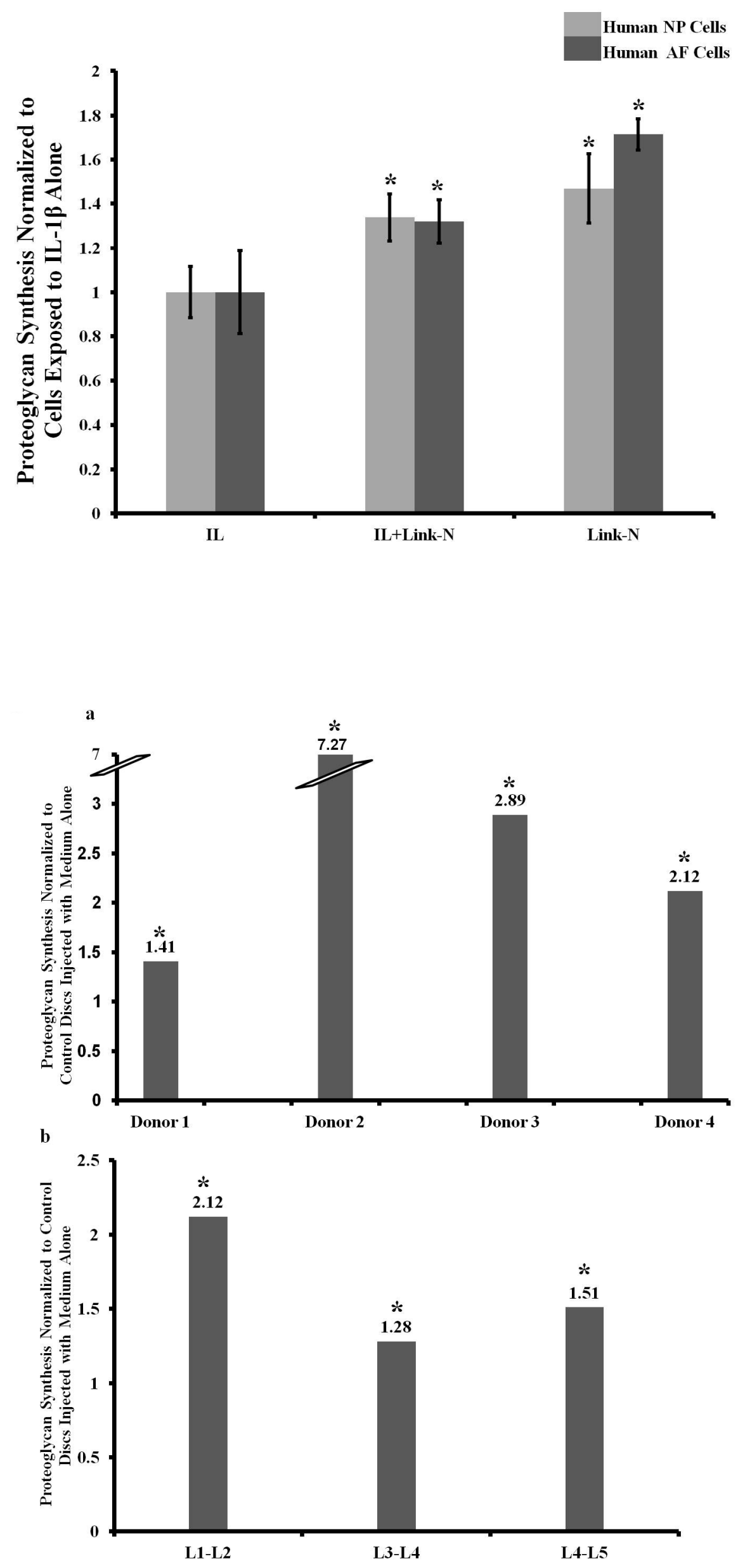

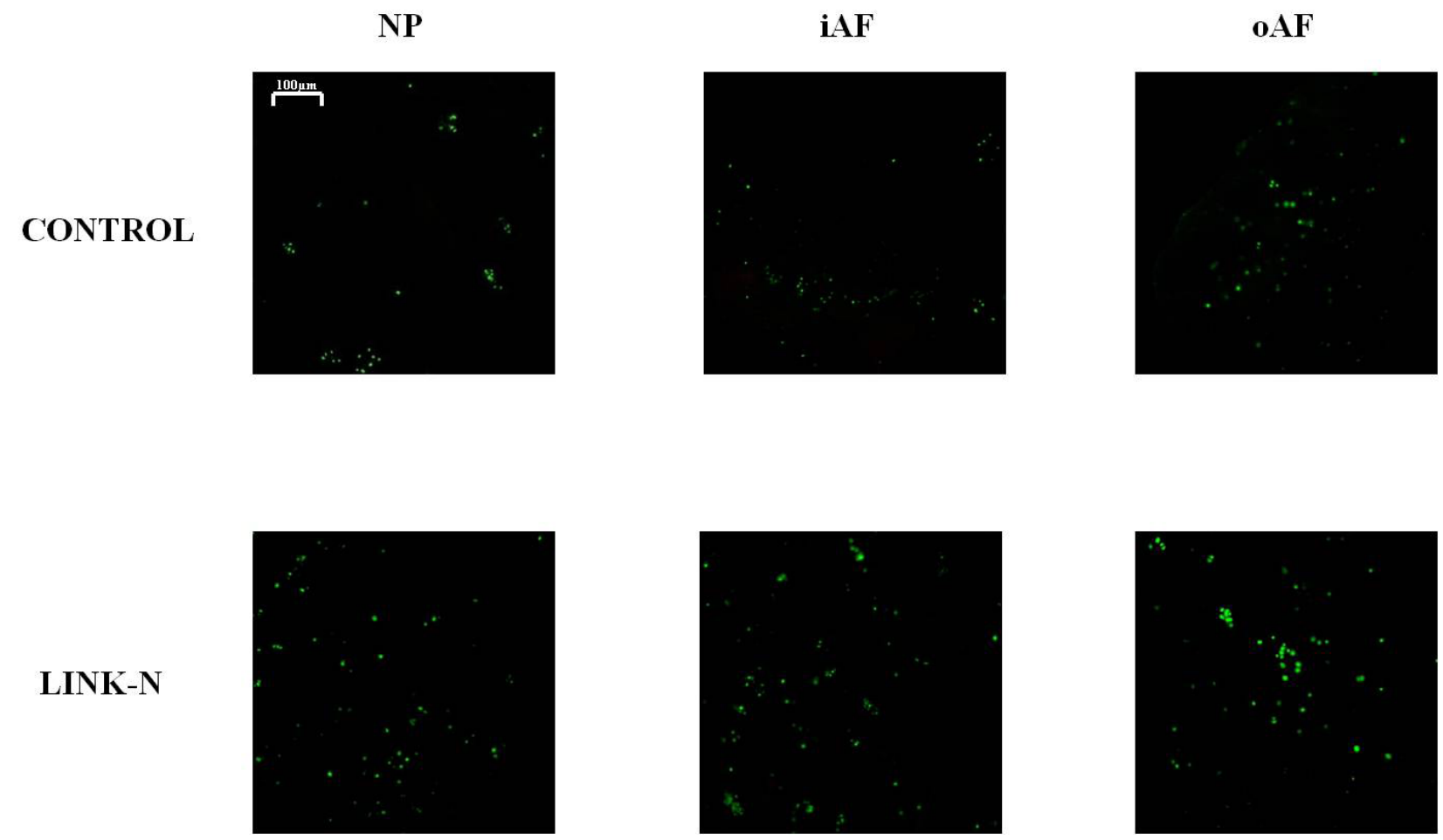

Fig. 6. Cell viability in human IVDs injected with Link-N. Viability was measured using the LIVE/DEAD ${ }^{\circledR}$ Viability/ Cytotoxicity Assay. Intact human IVDs were injected with $1 \mathrm{mg} /$ disc Link-N. Control discs were injected with media. After 7 days of culture, the discs were harvested and cell viability assessed across various areas of the disc. Green cells represent live cells and barely any dead cells (represented by red) were seen. Viability assessed at $>98 \%$.

Fig. 7. Sustained effect of Link-N on proteoglycan synthesis in intact human discs. Intact human IVDs were injected with ${ }^{35} \mathrm{SO}_{4} 7$ days post Link-N (1 $\mathrm{mg} /$ disc) injection. Discs were harvested and proteoglycan synthesis was evaluated by estimating ${ }^{35} \mathrm{SO}_{4}$ incorporation in intact human IVDs matched to their adjacent level controls in grade of degeneration. Data are expressed as a ratio relative to control discs injected with medium alone set at 1 .

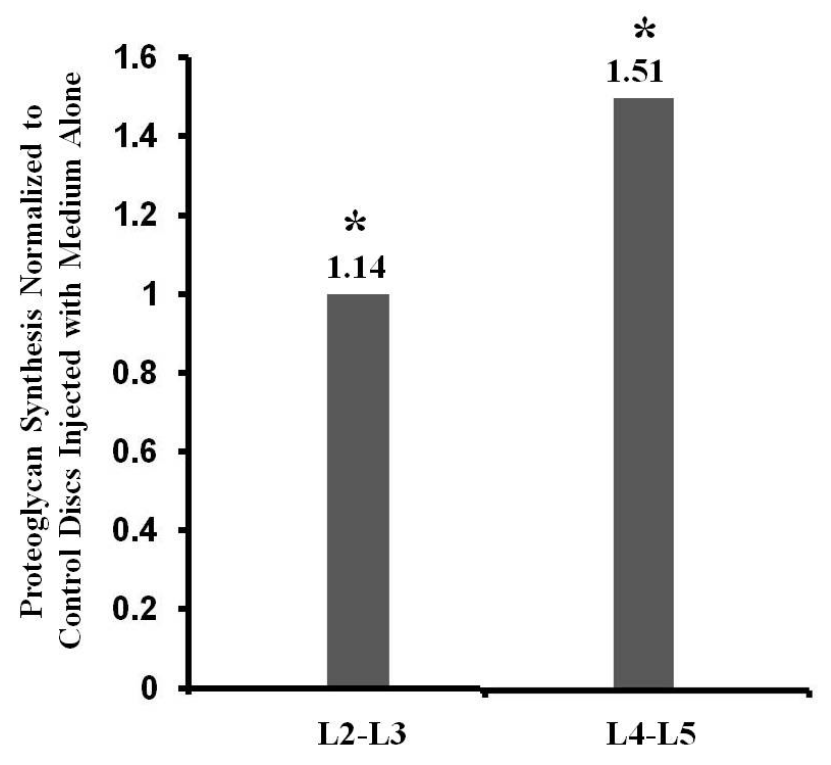

three different human donors were exposed to $1 \mu \mathrm{g} / \mathrm{mL}$ Link-N. Proteoglycan synthesis was stimulated in cells from all donors, but the extent was donor dependent (Fig. 1C). Values where $p \leq 0.05(*)$ were taken as significant.

\section{The effect of Link-N on matrix metabolism}

To investigate the effect of Link-N on proteinase and proteoglycan expression, human disc cells were exposed to $1 \mu \mathrm{g} / \mathrm{mL}$ Link-N for $24 \mathrm{~h}$ and relative gene expression was evaluated for aggrecan, MMP-3, MMP-13, ADAMTS-4 and ADAMTS-5. Results are expressed relative to cells unexposed to Link-N (Fig. 2). Aggrecan gene expression was upregulated by Link-N in both human NP and AF cells (NP $p=0.021, \mathrm{AF} p=0.003)$, though AF cells demonstrated higher aggrecan gene expression and a higher degree of stimulation when compared to NP cells $(p=0.027)$. MMP3 expression was upregulated by Link-N in both NP and AF cells (NP $p=0.009$, AF $p=0.001)$. MMP-13, ADAMTS-4 and ADAMTS-5 expression was downregulated by Link-N in NP cells $(p=0.0003, p=0.003, p=0.005)$, whereas 
Fig 8. 5-TAMRA linked Link-N was injected in NP region of intact IVDs (a) and was observed at the endplates at equilibrium (b). Punches were taken at equilibrium across various regions of the injected disc (c). Link-N was mostly detected at the site of injection NP and in the surrounding iAF region (d). No Link-N was detected in the medium or outer $\mathrm{AF}$ at the time of equilibrium. a

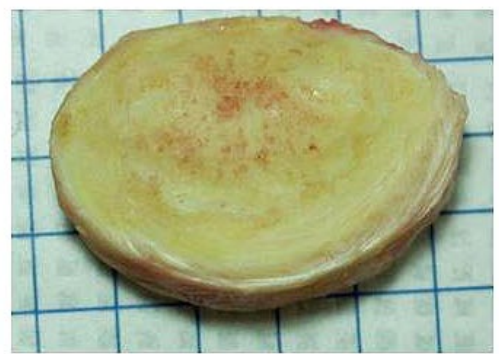

Pre-Injection

d

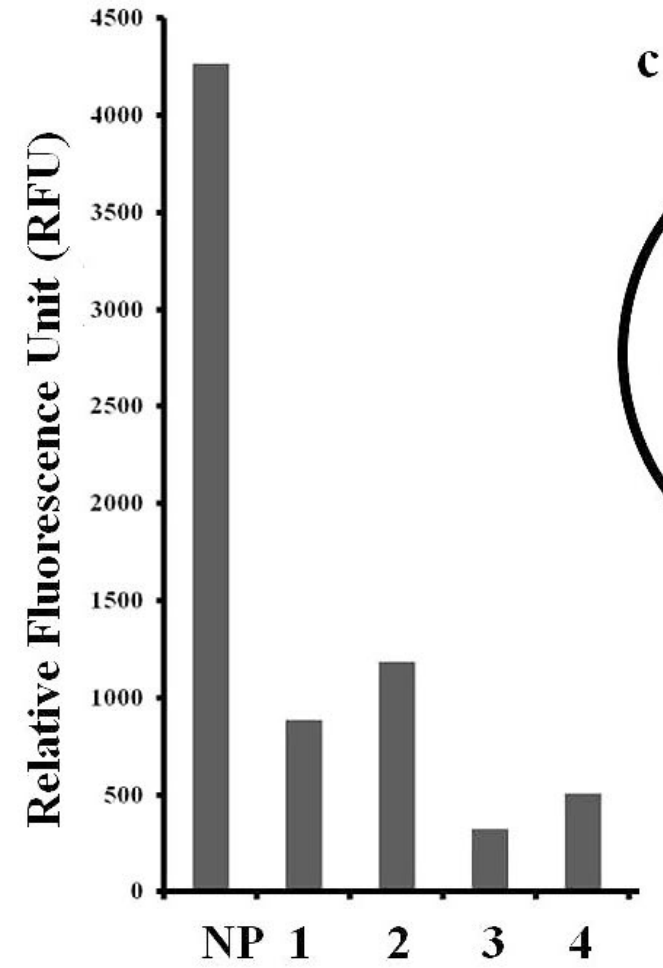

\section{c}

b

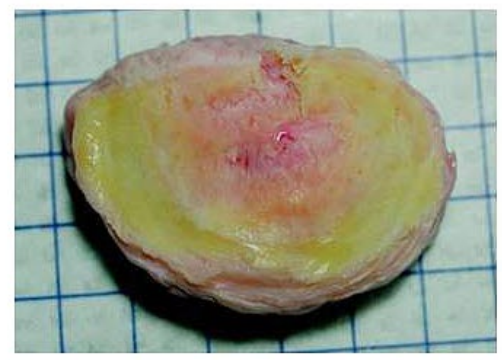

During Diffusion

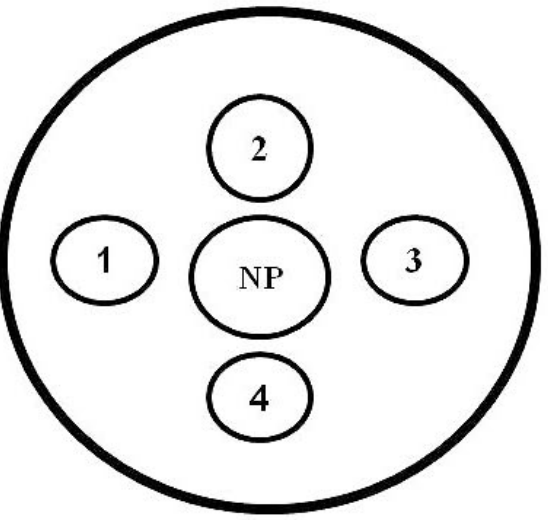

their expression was upregulated in AF cells $(p=0.002$, $p=0.002, p=0.003)$. Values where $p \leq 0.05(*)$ were taken as significant.

\section{The effect of Link-N on matrix metabolism in an inflammatory milieu}

As disc degeneration is closely linked to the presence of inflammatory cytokines in vivo, response to Link-N by human disc cells was evaluated in the presence of IL-1 $\beta$. Results are expressed relative to exposure to IL-1 $\beta$ alone (Fig. 3). Aggrecan gene expression was upregulated in NP $(p=0.004)$ and particularly in AF $(p=0.004)$ cells in response to Link-N even in the presence IL-1 $\beta$. AF cells showed stronger gene upregulation of aggrecan than NP cells $(p=0.0008)$. MMP-3, MMP-13, ADAMTS-4 and ADAMTS-5 gene expression levels were downregulated in NP cells, whereas upregulation of MMP-3 and ADAMTS-5 and downregulation of MMP-13 and ADAMTS-4 genes was observed in AF cells.

Proteoglycan synthesis was also evaluated using ${ }^{35} \mathrm{SO}_{4}$ incorporation. Link-N induced proteoglycan production in the presence of IL-1 $\beta$, with levels approaching to those observed in response to Link-N alone (Fig. 4). Proteoglycan production by NP and AF cells was similar in the presence of both Link-N and IL-1 $\beta$, in contrast to Link-N alone where AF cells showed more proteoglycan synthesis than NP cells. Taken together, our data indicate that Link-N has a protective effect with a down regulation of proteases such as MMP-3, MMP-13, ADAMTS-4 and ADAMTS-5 in NP cells $(p=0.005, p=0.004, p=0.004$, $p=0.006)$ and MMP-13 and ADAMTS-4 in AF cells $(p=0.003, p=0.004)$ and an upregulation of proteoglycan synthesis also in an inflammatory milieu. Values where

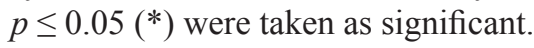

\section{The effect of Link-N in intact human discs}

To evaluate the potential of Link-N to promote proteoglycan synthesis in intact discs, intact human L2-L3 discs from four donors were injected with $1 \mathrm{mg} /$ disc Link-N. L1-L2 discs, injected with buffer without Link-N were used as controls. Although the response was donor dependent, Link-N stimulated proteoglycan synthesis in every disc, demonstrating the potential of Link-N to induce repair in an in situ environment (Fig. 5 A). Link-N or buffer 
alone was also injected into multiple discs from the same donor, to evaluate level dependent variability between the discs. All the injected discs showed response to Link-N but the magnitude varied, indicating that disc level and varying degree of degeneration within the same spine might influence the magnitude of the response to Link-N (Fig. 5 B).

\section{Cell viability in human IVDs injected with Link-N}

To verify that injection of $1 \mathrm{mg} / \mathrm{mL}$ Link-N was not detrimental to the cells, viability was assessed. Human discs were injected and cultured for a period of 7 days. Cell viability was maintained at $>98 \%$ at all sites in both discs injected with Link-N and control discs injected with medium alone (Fig. 6). Live cells fluoresce green and dead cells fluoresce red. Barely any red fluorescing dead cells were visualized.

\section{Sustained effect of Link-N injection in intact human discs}

Link-N was injected into intact human discs and ${ }^{35} \mathrm{SO}_{4}$ was then injected 7 days later to evaluate if there is a sustained effect of Link-N on proteoglycan synthesis. Increased proteoglycan synthesis was observed in all Link-N injected discs after 7 days. The response was somewhat variable between individual discs (Fig. 7).

\section{Diffusion of Link-N within intact human IVD}

Fluorescent Link-N peptide (with $\mathrm{N}$ terminal 5-TAMRA) was injected into intact human discs and distribution of the fluorescent peptide was evaluated. Link-N diffused laterally within the disc and vertically through endplates (Fig. 8A). Fluorescent Link-N started to appear at the endplates $12 \mathrm{~h}$ post injection. At $36 \mathrm{~h}$, the detection of fluorescent Link- $\mathrm{N}$ in the surrounding medium reached a maximum. At this point fluorescent Link-N within the disc was restricted to endplates over the NP and iAF/NP regions, with no detection in the oAF region (Fig. 8B). After repeated medium changes, Link-N was retained within the NP and iAF region (Fig. 8 C,D). Retention of the fluorescent Link-N was due to the peptide rather than to the fluorophore, as free 5-TAMRA was not retained.

\section{Discussion}

Previous studies have shown that Link-N can act as a growth factor and stimulate the synthesis of proteoglycans and collagens in articular cartilage (McKenna et al., 1998), bovine IVD cells in vitro (Mwale et al., 2003; Petit et al., 2011), as well as in a rabbit model of disc degeneration (Mwale et al., 2011). The present study indicates that Link-N can also stimulate proteoglycan synthesis by human disc cells in a 3-D scaffold as well as in intact human discs. This stimulation occurs with both NP and AF cells, although AF cells generally showed a greater stimulation of proteoglycan synthesis than NP cells. In addition to stimulating proteoglycan synthesis in intact intervertebral discs (Gawri et al., 2011), Link-N was also able to down-regulate metalloproteinase gene expression in an inflammatory milieu in NP cells and some proteinases in AF cells. The increase in proteoglycan synthesis in intact discs was sustained up to 9 days after Link-N injection. Link-N diffused within the disc and could be lost by diffusion through end plates, but its lateral diffusion was restricted by the outer AF. However a portion is retained in the NP region.

Various organ culture systems have been in development and use: (1) culture of discs without endplates (Chiba et al., 1998), (2) with vertebral bone (Lee et al., 2006; IllienJunger et al., 2010; Chan and Gantenbein-Ritter, 2012b) and (3) with cartilaginous endplates (Gawri et al., 2011; Jim et al., 2011). Organ culture systems except for those retaining only the cartilaginous endplate model were unable to maintain high cell viability even for short durations of culture; whereas the cartilaginous endplate model for human disc culture developed by us has overcome this problem. This is the first study of its kind utilizing human discs in organ culture for evaluating growth factor-like peptides. One of the limitations of this organ culture system though is the lack of diurnal variation in applied loads.

Stimulation of production of new proteoglycans under the influence of Link- $\mathrm{N}$ was studied by evaluating ${ }^{35} \mathrm{SO}_{4}$ incorporation. Sulfate can be incorporated into other sulfated proteoglycans other than aggrecan, including biglycan, decorin and versican. Such proteoglycans may be present in similar (biglycan and decorin) or lower (versican) molar concentrations when compared to aggrecan. However, aggrecan has many more chondroitin sulfate chains than other proteoglycans and hence is the major site for sulfate incorporation. The present work measures proteoglycan synthesis under static loading conditions, which raises the question of whether a similar response would be seen under more physiological dynamic loading. As current data suggests that dynamic loading stimulates proteoglycan synthesis (Korecki et al., 2008), there is no reason to believe that dynamic loading would adversely affect the ability of Link-N to stimulate proteoglycan synthesis. Indeed, it may enhance the effect.

In this study, even though high proteoglycan content in the disc is commonly associated with NP, AF cells respond better than NP cells to Link-N in promoting proteoglycan synthesis. The ability of AF cells to respond more strongly than NP cells to Link-N in stimulating proteoglycan synthesis has also been reported previously with other growth factors (Imai et al., 2007a). In earlier work with bovine disc cells, it was found that AF cells were capable of producing more proteoglycan than NP cells when stimulated with TGF- $\beta$ (Roughley et al., 2006a). However, other studies with bovine cells reported that NP and AF cells were capable of responding in a similar manner when cultured on 3D polyester mesh (Chou et al., 2008). In young human discs, NP is the main source of proteoglycan, but with age and degeneration there is an increased proteoglycan content in the AF (Alini et al., 2002) and much of the proteoglycan needed to maintain disc function is presumably synthesized by the AF. Thus, it is not surprising that proteoglycan synthesis can be strongly stimulated in the AF cells from adults.

Assuming that diffusion of Link-N results in a uniform distribution between the disc and medium, the dose of Link-N injected in intact discs was about $20 \mathrm{X}$ more than 
the dose of maximal response determined in 3D cultures of isolated disc cells. This dose was chosen based on the assumption that only about $5 \%$ of the injected Link-N would be available to disc cells due to binding of Link-N to disc matrix and digestion by tissue MMPs. If this assumption is correct, the dose available to disc cells in intact disc organ culture would be about $1 \mu \mathrm{g} / \mathrm{mL}$. In preliminary experiments, intact discs were also injected with 0.1 and $0.5 \mathrm{mg}$ of Link-N, but $1 \mathrm{mg} /$ disc was found to result in the best response. This dose might not be the dose of maximal response in intact discs, but was not detrimental to the cells, as the cell viability in both control and Link-N injected discs was maintained at $>96 \%$.

Stimulation of proteoglycan by Link-N may not only depend on the cell type, but also on disc level within the same donor. It is not clear whether our observations on the variability in proteoglycan stimulation by Link- $\mathrm{N}$ is a universal phenomenon with all growth factors. The ability of Link-N to stimulate matrix repair may vary due to differences in age and gender, as well as nutritional status, size, cell density and grade of degeneration, which vary within the same individual. These factors may influence patient selection for growth factor therapy for degenerative disc disease. While preparing discs for organ cultures, we have observed varying degrees of both degeneration and calcification within discs from the same individual. This could be attributed to various systemic factors implicated in disc degeneration. Intraspinal variation indicates that every disc behaves as a separate entity and thus disc selection within the same individual is also crucial in having a desired optimal effect following Link-N treatment.

The ability of Link-N injected in intact human discs to have a sustained effect, is analogous to previous reports for other growth factors (Masuda et al., 2006), and could be of practical significance in circumventing the need for repeated injections if used therapeutically. The mechanism by which Link-N causes a sustained effect is unclear. One possibility is that its retention in the inner AF and NP is due to interaction with the extracellular matrix (ECM), causing it to be released slowly to the cells. Another possibility is that Link-N may have a long half-life within the tissue.

Disc degeneration in vivo is a process resulting from years of increased catabolism of the disc matrix involving various cytokines which upregulate proteases (Lee et al., 2009; Cuellar et al., 2010; Shamji et al., 2010; Wang et al., 2011). If a bioactive agent is to reverse and/or retard the degenerative process in the disc, it should be able to exert its anabolic effect in this inflammatory milieu. Link-N stimulated proteoglycan synthesis in the presence of inflammatory cytokines, thus showing the potential for regeneration in ongoing disc matrix degeneration. At the dose of maximal response, Link-N induced an upregulation of aggrecan in both NP and AF cells. NP cells showed a more favorable response to Link- $\mathrm{N}$ with an increase in gene expression for aggrecan and a downregulation of the expression levels of the proteases MMP-3, MMP-13, ADAMTS-4 and ADAMTS-5 in the presence of IL- $1 \beta$.

In this study, AF cells showed upregulation of MMP3 and ADAMTS-5 gene expression by Link-N in the absence or presence of IL-1 $\beta$. It is commonly believed that remodeling of the newly laid down matrix is crucial to generating a functional matrix. This involves upregulation of various proteases. Only time will tell if the upregulation of MMP-3 and ADAMTS-5 observed here is due to remodeling. Regardless, Link-N does appear to be effective at stimulating proteoglycan production by the AF to help restore disc function.

Many recombinant growth factors such as GDF-5, OP1, and IGF-1 have been shown to increase proteoglycan synthesis by rabbit and bovine disc cells (Masuda, 2008). OP-1 was injected in rabbit discs after inducing degeneration with chondroitinase $\mathrm{ABC}$ and showed restoration of disc height (Imai et al., 2007b). TGF- $\beta$ has been shown to rescue the decrease in proteoglycan production by IL- $1 \beta$ in cartilage explants, but interestingly co-injection of TGF- $\beta$ and IL- $1 \beta$ was not able to show a rescue effect (Van Beuningen et al., 1994). Similarly, induction of proteoglycan synthesis under the influence of TGF- $\beta$ was shown in intact disc culture model of intervertebral disc (Jim et al., 2011). In these studies, tissues from younger animals were used and degeneration induced. The present study is first of its kind to show that Link-N can induce proteoglycan synthesis in human disc cells in an inflammatory milieu. This establishes the potential of Link-N to be active when injected into human discs in vivo. Furthermore, Link-N has a significant cost advantage over other tested recombinant growth factors. Based on prior in vivo studies in the rabbit, Link-N is over a 100 times less expensive than recombinant growth factors that have a similar repair response.

The regenerative potential of Link-N has been studied in many systems (Mwale et al., 2003; Mwale et al., 2011; Antoniou et al., 2012; Abbott et al., 2013), and in the present study human disc cells from NP and AF in their microenvironment, under the influence of Link-N, showed increase in aggrecan synthesis and downregulation of proteases by NP cells. In contrast, recent work by Abbott et al. (Abbott et al., 2013) evaluated the effect of Link-N, CTGF and TGF- $\beta+$ Dex on human disc cells in alginate. The study did not show much upregulation of aggrecan by disc cells exposed to Link-N compared to other experimental groups. Furthermore, MMP-3 was upregulated whereas in our evaluation there was a downregulation. This difference could be attributed to the source of tissue, which in this case was from moderate to severely degenerated surgically removed discs where it is difficult to separate the different regions of discs due to loss of gross morphology. This leads to a mixed population of cells going in culture. Also, in contrast to our study, Abbott et al. expanded the cells to increase cell numbers before embedding in 3-D scaffolds, which could influence the phenotype of cells (Kandel et al., 2008). Importantly, the dose of Link-N used was 10 times less than the dose of maximal response reported by us for human disc cells. Another recent study by Wang et al. (Wang et al., 2013) evaluated the effects of Link-N on human NP cells from surgical donors in producing ECM components; both at the gene expression and protein levels, which showed increased production aggrecan and collagen type 2 but no effect on proteases production. In this study again, expanded disc cells were used and the maximal response dose used was 5 times less than the one evaluated by us. There was a trend towards increase 
in ECM protein production with increasing doses, but doses greater than $200 \mathrm{ng} / \mathrm{mL}$ were neither evaluated nor used, which might explain protease production remaining unaffected by Link-N contrary to results shown by us. In the present study, even though the increase in aggrecan gene expression and proteoglycan synthesis may be small in magnitude, it demonstrates the pro-anabolic potential of Link-N as these changes if maintained over an extended time-frame following Link-N administration may restore the functional properties of the disc.

Link-N is a promising bioactive peptide for treatment of degenerative disc disease. However, the target cohort of patients would preferably be those with mild disc degeneration where the AF remains intact and responds to Link-N. Beyond Thompson grade 3, surgical treatment would be the mainstay treatment due to severely depleted cell population and the disrupted integrity of the disc. Link-N therapy thus may not be able to repair higher grades of degeneration where annular fissures and tears are present, although it could be used post-surgery to delay adjacent level disc disease (Kulkarni and Hee, 2006; Lund and Oxland, 2011).

\section{Conclusions}

In conclusion, Link-N is a promising agent for biological repair of degenerated human discs but its success in repairing disc degeneration will largely depend upon patient selection. In the future, an alternative therapeutic delivery system for Link-N that would avoid the need for injection would greatly enhance its acceptance as a valid therapeutic option. With the potential of Link-N in stimulating matrix synthesis and development of an alternate delivery system, this peptide could be taken to the stage of clinical human trials and be used as a therapeutic agent for treating degenerative disc disease.

\section{Acknowledgements}

The authors would like to thank our funding sources AO Spine, North American Spine Society (NASS) and Canadian Institute of Health Sciences (CIHR). We would also like to thank Transplant Quebec for coordinating the retrieval of human lumbar spines through organ donation program.

\section{References}

Abbott RD, Purmessur D, Monsey RD, Brigstock DR, Laudier DM, Iatridis JC (2013) Degenerative grade affects the responses of human nucleus pulposus cells to link-N, CTGF, and TGFbeta3. J Spinal Disord Tech 26: E86-94.

Akyol S, Eraslan BS, Etyemez H, Tanriverdi T, Hanci M (2010) Catabolic cytokine expressions in patients with degenerative disc disease. Turk Neurosurg 20: 492-499.

Alini M, Roughley PJ, Antoniou J, Stoll T, Aebi M (2002) A biological approach to treating disc degeneration: not for today, but maybe for tomorrow. Eur Spine J 11 Suppl 2: S215-220.
Anderson DG, Risbud MV, Shapiro IM, Vaccaro AR, Albert TJ (2005) Cell-based therapy for disc repair. Spine J 5: 297S-303S.

Antoniou J, Wang HT, Alaseem AM, Haglund L, Roughley PJ, Mwale F (2012) The effect of Link-N on differentiation of human bone marrow-derived mesenchymal stem cells. Arthritis Res Ther 14: R267.

Boyd LM, Carter AJ (2006) Injectable biomaterials and vertebral endplate treatment for repair and regeneration of the intervertebral disc. Eur Spine J 15 Suppl 3: S414-421.

Chadderdon RC, Shimer AL, Gilbertson LG, Kang JD (2004) Advances in gene therapy for intervertebral disc degeneration. Spine J 4: 341S-347S.

Chan SC, Gantenbein-Ritter B (2012a) Intervertebral disc regeneration or repair with biomaterials and stem cell therapy--feasible or fiction? Swiss Med Wkly 142: w13598.

Chan SC, Gantenbein-Ritter B (2012b) Preparation of intact bovine tail intervertebral discs for organ culture. $\mathrm{J}$ Vis Exp, in press.

Chiba K, Andersson GB, Masuda K, Momohara S, Williams JM, Thonar EJ (1998) A new culture system to study the metabolism of the intervertebral disc in vitro. Spine 23: 1821-1827; discussion 1828.

Chou AI, Reza AT, Nicoll SB (2008) Distinct intervertebral disc cell populations adopt similar phenotypes in three-dimensional culture. Tissue Eng Part A 14: 2079-2087.

Chung SA, Khan SN, Diwan AD (2003) The molecular basis of intervertebral disk degeneration. Orthop Clin North Am 34: 209-219.

Cuellar JM, Golish SR, Reuter MW, Cuellar VG, Angst MS, Carragee EJ, Yeomans DC, Scuderi GJ (2010) Cytokine evaluation in individuals with low back pain using discographic lavage. Spine J 10: 212-218.

Dagenais S, Caro J, Haldeman S (2008) A systematic review of low back pain cost of illness studies in the United States and internationally. Spine J 8: 8-20.

Donohue PJ, Jahnke MR, Blaha JD, Caterson B (1988) Characterization of link protein(s) from human intervertebral-disc tissues. Biochem J 251: 739-747.

Engel CC, Von Korff M, Katon WJ (1996) Back pain in primary care: predictors of high health-care costs. Pain 65: 197-204.

Freemont AJ, Watkins A, Le Maitre C, Jeziorska M, Hoyland JA (2002) Current understanding of cellular and molecular events in intervertebral disc degeneration: implications for therapy. J Pathol 196: 374-379.

Frymoyer JW, Cats-Baril WL (1991) An overview of the incidences and costs of low back pain. Orthop Clin North Am 22: 263-271.

Gawri R, Mwale F, Ouellet J, Roughley PJ, Steffen T, Antoniou J, Haglund L (2011) Development of an organ culture system for long-term survival of the intact human intervertebral disc. Spine 36: 1835-1842.

Hollander AP, Heathfield TF, Webber C, Iwata Y, Bourne R, Rorabeck C, Poole AR (1994) Increased damage to type II collagen in osteoarthritic articular cartilage detected by a new immunoassay. J Clin Invest 93: 17221732. 
Illien-Junger S, Gantenbein-Ritter B, Grad S, Lezuo P, Ferguson SJ, Alini M, Ito K (2010) The combined effects of limited nutrition and high-frequency loading on intervertebral discs with endplates. Spine 35: 1744-1752.

Imai Y, Miyamoto K, An HS, Thonar EJ, Andersson GB, Masuda K (2007a) Recombinant human osteogenic protein-1 upregulates proteoglycan metabolism of human anulus fibrosus and nucleus pulposus cells. Spine 32: 1303 1309; discussion 1310.

Imai Y, Okuma M, An HS, Nakagawa K, Yamada M, Muehleman C, Thonar E, Masuda K (2007b) Restoration of disc height loss by recombinant human osteogenic protein-1 injection into intervertebral discs undergoing degeneration induced by an intradiscal injection of chondroitinase ABC. Spine 32: 1197-1205.

Jim B, Steffen T, Moir J, Roughley P, Haglund L (2011) Development of an intact intervertebral disc organ culture system in which degeneration can be induced as a prelude to studying repair potential. Eur Spine J 20: 1244-1254.

Kandel R, Roberts S, Urban JP (2008) Tissue engineering and the intervertebral disc: the challenges. Eur Spine J 17 Suppl 4: 480-491.

Korecki CL, MacLean JJ, Iatridis JC (2008) Dynamic compression effects on intervertebral disc mechanics and biology. Spine 33: 1403-1409.

Kulkarni AG, Hee HT (2006) Adjacent level discitis after anterior cervical discectomy and fusion (ACDF): a case report. Eur Spine J 15 Suppl 5: 559-563.

Lee CR, Iatridis JC, Poveda L, Alini M (2006) In vitro organ culture of the bovine intervertebral disc: effects of vertebral endplate and potential for mechanobiology studies. Spine 31: 515-522.

Lee S, Moon CS, Sul D, Lee J, Bae M, Hong Y, Lee M, Choi S, Derby R, Kim BJ, Kim J, Yoon JS, Wolfer L, Kim J, Wang J, Hwang SW, Lee SH (2009) Comparison of growth factor and cytokine expression in patients with degenerated disc disease and herniated nucleus pulposus. Clin Biochem 42: 1504-1511.

Le Maitre CL, Freemont AJ, Hoyland JA (2005) The role of interleukin-1 in the pathogenesis of human intervertebral disc degeneration. Arthritis Res Ther 7: R732-745.

Livak KJ, Schmittgen TD (2001) Analysis of relative gene expression data using real-time quantitative PCR and the 2(-Delta Delta C(T)) method. Methods 25: 402-408.

Lund T, Oxland TR (2011) Adjacent level disk disease - is it really a fusion disease? Orthop Clin North Am 42: 529-541, viii.

Luo X, Pietrobon R, Sun SX, Liu GG, Hey L (2004) Estimates and patterns of direct health care expenditures among individuals with back pain in the United States. Spine 29: 79-86.

Luoma K, Riihimaki H, Luukkonen R, Raininko R, Viikari-Juntura E, Lamminen A (2000) Low back pain in relation to lumbar disc degeneration. Spine 25: 487-492.

Maldonado BA, Oegema TR Jr (1992) Initial characterization of the metabolism of intervertebral disc cells encapsulated in microspheres. J Orthop Res 10: 677 690 .

Malemud CJ, Killeen W, Hering TM, Purchio AF (1991) Enhanced sulfated-proteoglycan core protein synthesis by incubation of rabbit chondrocytes with recombinant transforming growth factor-beta 1. J Cell Physiol 149: 152-159.

Mapel DW, Shainline M, Paez K, Gunter M (2004) Hospital, pharmacy, and outpatient costs for osteoarthritis and chronic back pain. J Rheumatol 31: 573-583.

Masuda K (2008) Biological repair of the degenerated intervertebral disc by the injection of growth factors. Eur Spine J 17 Suppl 4: 441-451.

Masuda K, Oegema TR Jr, An HS (2004) Growth factors and treatment of intervertebral disc degeneration. Spine 29: 2757-2769.

Masuda K, Imai Y, Okuma M, Muehleman C, Nakagawa K, Akeda K, Thonar E, Andersson G, An HS (2006) Osteogenic protein-1 injection into a degenerated disc induces the restoration of disc height and structural changes in the rabbit anular puncture model. Spine 31: 742-754.

McKenna LA, Liu H, Sansom PA, Dean MF (1998) An N-terminal peptide from link protein stimulates proteoglycan biosynthesis in human articular cartilage in vitro. Arthritis Rheum 41: 157-162.

Melching LI, Roughley PJ (1985) The role of link protein in mediating the interaction between hyaluronic acid and newly secreted proteoglycan subunits from adult human articular cartilage. J Biol Chem 260: 16279-16285.

Mwale F, Demers CN, Petit A, Roughley P, Poole AR, Steffen T, Aebi M, Antoniou J (2003) A synthetic peptide of link protein stimulates the biosynthesis of collagens II, IX and proteoglycan by cells of the intervertebral disc. J Cell Biochem 88: 1202-1213.

Mwale F, Masuda K, Pichika R, Epure LM, Yoshikawa T, Hemmad A, Roughley PJ, Antoniou J (2011) The efficacy of Link-N as a mediator of repair in a rabbit model of intervertebral disc degeneration. Arthritis Res Ther 13: R120.

Petit A, Yao G, Rowas SA, Gawri R, Epure L, Antoniou J, Mwale F (2011) Effect of synthetic Link-N peptide on the expression of type I and type II collagens in human intervertebral disc cells. Tissue Eng Part A 17: 899-904.

Roughley PJ (2004) Biology of intervertebral disc aging and degeneration: involvement of the extracellular matrix. Spine 29: 2691-2699.

Roughley P, Hoemann C, DesRosiers E, Mwale F, Antoniou J, Alini M (2006a) The potential of chitosanbased gels containing intervertebral disc cells for nucleus pulposus supplementation. Biomaterials 27: 388-396.

Roughley PJ, Melching LI, Heathfield TF, Pearce RH, Mort JS (2006b) The structure and degradation of aggrecan in human intervertebral disc. Eur Spine J 15 Suppl 3: S326-332.

Shamji MF, Setton LA, Jarvis W, So S, Chen J, Jing L, Bullock R, Isaacs RE, Brown C, Richardson WJ (2010) Proinflammatory cytokine expression profile in degenerated and herniated human intervertebral disc tissues. Arthritis Rheum 62: 1974-1982.

Van Beuningen HM, Van der Kraan PM, Arntz OJ, Van den Berg WB (1994) In vivo protection against interleukin1-induced articular cartilage damage by transforming growth factor-beta 1: age-related differences. Ann Rheum Dis 53: 593-600. 
Wang J, Markova D, Anderson DG, Zheng Z, Shapiro IM, Risbud MV (2011) TNF-alpha and IL-1beta promote a disintegrin-like and metalloprotease with thrombospondin type I motif-5-mediated aggrecan degradation through syndecan-4 in intervertebral disc. J Biol Chem 286: 3973839749.

Wang Z, Hutton WC, Yoon ST (2013) ISSLS prize winner: the effect of Link protein peptide (LPP) on human intervertebral disc cells. Spine 38: 1501-1507.

Woods BI, Vo N, Sowa G, Kang JD (2011) Gene therapy for intervertebral disk degeneration. Orthop Clin North Am 42: 563-574, ix.

Yoon ST (2005) Molecular therapy of the intervertebral disc. Spine J 5: 280S-286S.

Zhao CQ, Wang LM, Jiang LS, Dai LY (2007) The cell biology of intervertebral disc aging and degeneration. Ageing Res Rev 6: 247-261.

\section{Discussion with Reviewers}

B. Johnstone: The authors performed a study in which they addressed human variability within the context of system limitations (e.g., high replication is impossible for human organ culture). Since the authors are leading the way in human organ culture techniques, could they comment on their choices and recommendations for addressing human variation in this type of model system?

Authors: We are grateful for the opportunity to address the high variability encountered with human discs. Not only is the variation present between donors but even the discs from the same donor show difference in level due to variation in both degeneration and size, making each individual disc unique. One way to minimize variation in results is to evaluate the grade of degeneration radiologically before commencing experiments (done as routine by our group) or if resources permit by MRI, and group the discs with similar degeneration and size in the same experimental group to avoid bias and variability. Another approach adopted by us is choosing adjacent level discs from the same donor with similar grades of degeneration as control and experimental discs. 